\title{
Access Barriers to the Utilization of Adolescent Reproductive Health Information
}

\author{
Wulan Rahmadhani ${ }^{*}$, Lutfia Uli Na'mah ${ }^{1}$, Adinda Putri Sari Dewi ${ }^{1}$, Than Kyaw Soe ${ }^{2}$ \\ ${ }^{1}$ Departement of Midwifery, Universitas Muhamadiyah Gombong \\ ${ }^{2}$ Water Sanitation and Hygiene, United Nations Children's Founds (UNICEF), Myanmar \\ * corresponding author: wulannnnn02@gmail.com
}

ARTICLE INFO

Article history

Received 09/01/2022

Revised 15/01/2022

Accepted 18/01/2022

Keywords

Access Barriers

Reproductive Health Information Adolescents

\begin{abstract}
Background: Reproductive health issues need to be considered by various parties. The low utilization of adolescent health services still becomes a key issue. The availability of services and the need to access information cannot increase access if adolescents are still experiencing various challenges. This study aims to determine the factors affecting access to reproductive health information. Methods: This observational research used a cross-sectional approach. The population was all adolescents in Kebumen district determined with proportional random sampling technique with a total of 560 samples. The data were then analyzed using univariate analysis to determine the percentage, bivariate analysis, and multivariate analysis of logistic regression test with $95 \% \mathrm{Cl}$.Results: the results of the multivariate analysis showed that there is a relationship between cognitive access barriers, gender, type of household, psychosocial access to reproductive health information with a p-value of $<0.05$. Conclusion: adolescent health information should be conveyed intensively through the internet, especially mass media and social media.
\end{abstract}

\section{Introduction}

Adolescence means the period of growth to reach maturity in terms of mental, emotional, social, and physical [1]. Adolescence is marked by the rapid physical growth of individuals [2]. Physical growth has an impact on the psychological and social development of adolescents [3]. Based on the Statistics Indonesia, 63.4 million people are adolescents consisting of $50.7 \%$ males and $49.3 \%$ females [4].

Adolescents are often uncomfortable talking about sexual and reproductive health [5]. Indeed, they are curious about that information [6]. They feel that their parents refuse to talk about reproductive health so they look for other sources of information such as friends or the mass media [7]. The lack of knowledge and attitudes of adolescents regarding the importance of reproductive health services causes adolescents less to consider the importance of the service to protect them from the risk of early marriage, unwanted pregnancy, abortion, sexually transmitted infections (STI), HIV/AIDS, and sexual violence [8]. The unavailability of accurate information on reproductive health forces adolescents to seek access and explore more which can lead them to access less accurate information [9]. Then, they will face reproductive health issues [10].

One of the government programs to address adolescent reproductive health issues is the Youth Care Health Program (PKPR) [11]. In 2014 data show that only $81 \%$ of districts have at least 4 Puskesmas with PKPR. It is far from the target as there are only $45 \%$ of puskesmas that carried out PKPR in 2019 [6]. The availability of this program is not enough to improve adolescent health [1]. Adolescents need to be able to access information and the PKPR gets the benefits. Indonesian Health Demographic Survey (IDHS) revealed that $34 \%$ of young women knew about the health information and counseling services of PKPR and about $16 \%$ of them can access the services [12]. 
Ignorance about PKPR can be the cause of the adolescent's lack of knowledge about reproductive health [13]. Further, the 2017 IDHS data show that only $33 \%$ of female adolescents and $37 \%$ of male adolescents aged $15-19$ years have adequate knowledge about reproductive

health [13]. Adequate knowledge about comprehensive sexual and reproductive health directly or indirectly prevents various adverse effects on adolescent reproductive health [14]. Meanwhile, knowledge about access to reproductive health information and the factors influencing it are still limited [8]. Some of the factors are interpersonal communication skills, trust in health workers, and the perception of not needing information/services [15]. The other factors are not knowing the existence of PKPR (cognitive barriers), feelings of fear and shame in visiting the place (psychosocial barriers), structural barriers such as opening hours, waiting times for services, and service costs (economic barriers) [16]. Therefore, this study aims to analyze the barriers to access to reproductive health information.

\section{Materials and Method}

This observational study used a cross-sectional approach to see the barriers to access to reproductive health information. The population in this study was all adolescents aged 12-19 years in Kebumen District. It involved 560 respondents determined with the proportional random sampling technique. The independent variable in this study was access barriers (cognitive barriers and psychological barriers) and the dependent variable was access to reproductive health information through health workers. The research instrument was demographic data and self-administered questionnaires that have been tested for validity and reliability. The analysis used univariate analysis to determine the frequency distribution and bivariate analysis of simple logistic regression. If the value is lower than 0.25 , then the variable is included in the multivariate analysis. Multivariate analysis using logistic regression test of $95 \% \mathrm{Cl}$ (Confident interval), odds ratio (Adj OR), and a significant value of $>0.05$

\section{Results and Discussion}

\subsection{Results}

In this study, the characteristics of respondents are based on age, gender, religion, education, type of household, parents' income, cognitive barriers, psychosocial barriers, and access to reproductive health information. Of the total 560 respondents are aged $17.86 \pm 1.23$ and $340(60.7 \%)$ respondents are women. The table shows that $503(94.6 \%)$ respondents have high school education; $480(85.7 \%)$ respondents live with nuclear families; 540 respondents (94.6\%) are Muslims. A total of $328(58.6 \%)$ respondents have parents with low income, 302 (54\%) respondents do not experience cognitive impairment, $288(51.4 \%)$ respondents do not experience psychosocial barriers, and 292 $(52.1 \%)$ respondents do not access health information.

Table 1. Demographic characteristics of respondents

\begin{tabular}{lccc}
\hline & Characteristics & $\mathbf{n}$ & $\%$ \\
\hline Sex & Male & 220 & 39.3 \\
$\quad$ Female & 340 & 60.7 \\
Age & \multicolumn{2}{c}{$17.86 \pm 1.23$} \\
Religion & 530 & 94.6 \\
$\quad$ Islam & 30 & 5.4 \\
$\quad$ Christianity & 10 & 1.8 \\
Education & 20 & 3.6 \\
$\quad$ Primary School & 530 & 94.6 \\
$\quad$ Secondary School & & \\
$\quad$ High School & 480 & 85.7 \\
Type of household & 80 & 14.3 \\
$\quad$ Nuclear Family & & \\
$\quad$ Extended Family & &
\end{tabular}




\begin{tabular}{lcc}
\hline High & 328 & 58.6 \\
Low & 232 & 41.4 \\
Cognitive Barriers & & \\
No & 302 & 54 \\
Yes & 258 & 46 \\
Psychosocial Barriers & & \\
No & 288 & 51.4 \\
Yes & 272 & 48.6 \\
Access to Reproductive Health Information & & \\
Access & 268 & 47.9 \\
Not Access & 292 & 52.1 \\
\hline
\end{tabular}

Simple logistic regression indicates that the factors influencing access to health information are gender, type of household, parents' income, cognitive barriers, and psychosocial barriers that have a $p$-value $<0.25$. This variable was included in the multivariate analysis (Table 2 ).

Table 2. Bivariate Analysis of Barriers to Access to Reproductive Health Information: Simple

\begin{tabular}{|c|c|c|c|c|c|}
\hline \multicolumn{6}{|c|}{ Logistic Regression } \\
\hline Variable & $\mathbf{n}$ & $\%$ & Crude OR & $95 \% \mathrm{Cl}$ & p \\
\hline \multicolumn{6}{|l|}{ Sex } \\
\hline Male & 220 & 39.3 & 1 & \multirow[b]{2}{*}{$1.18-2.47$} & \multirow[t]{2}{*}{0.004} \\
\hline Female & 340 & 60.7 & 1.71 & & \\
\hline \multicolumn{6}{|l|}{ Education } \\
\hline Primary School & 10 & 1.8 & 1 & & \multirow[t]{3}{*}{0.289} \\
\hline Secondary School & 20 & 3.6 & 13.71 & & \\
\hline High School & 530 & 94.6 & 12.31 & $12.31-36.28$ & \\
\hline \multicolumn{6}{|l|}{ Type of household } \\
\hline Nuclear Family & 480 & 85.7 & 1 & & \multirow[t]{2}{*}{$<0.001$} \\
\hline Extended Family & 80 & 14.3 & 4.02 & $2.78-5.68$ & \\
\hline \multicolumn{6}{|l|}{ Parent's income } \\
\hline Low & 328 & 58.6 & 1 & & \multirow[t]{2}{*}{0.004} \\
\hline High & 232 & 41.4 & 9.53 & $1.98-3.99$ & \\
\hline \multicolumn{6}{|l|}{ Cognitive Barriers } \\
\hline No & 302 & 54 & 1 & & \multirow[t]{2}{*}{0.002} \\
\hline Yes & 258 & 46 & 3.88 & $0.88-3.16$ & \\
\hline \multicolumn{6}{|l|}{ Psychosocial Barriers } \\
\hline No & 288 & 51.4 & 1 & & \multirow[t]{2}{*}{0.008} \\
\hline Yes & 272 & 48.6 & 2.02 & $9.01-10.11$ & \\
\hline
\end{tabular}

The final model of multivariate analysis using multiple logistic regression show Sex (Adj OR 2.41, 95\% Cl 1.45 - 2.63; p-value <0.001), Type Household (Adj OR 2.67; 95\%Cl 1.05 - 3.60; $p$-value 0.001 ), Parents' income (Adj or 1.17; 95\%Cl $3.44-5.90$; $p$-value $<0.001$ ), Cognitive barriers (Adj OR 3.10; 95\%Cl 5. 09 - 6.98; p-value 0.000), Psychosocial barriers (Adj OR 4.21; 95\% $\mathrm{Cl} 1.11$ 4.78; p-value $<0.001)$. (Table 3)

Table 3. Multivariate Analysis of Barriers to Access to Reproductive Health Information: A Multiple

\begin{tabular}{|c|c|c|c|c|c|c|}
\hline \multicolumn{7}{|c|}{ Logistic Regression } \\
\hline Variable & $\mathbf{n}$ & $\%$ & $\begin{array}{c}\text { Crude } \\
\text { OR }\end{array}$ & $\begin{array}{c}\text { Adjusted } \\
\text { OR }\end{array}$ & $95 \% \mathrm{Cl}$ & p \\
\hline \multicolumn{7}{|l|}{ Sex } \\
\hline Male & 220 & 39.3 & 1 & & & \multirow[t]{2}{*}{$<0.001$} \\
\hline Female & 340 & 60.7 & 2.57 & 2.41 & $1.45-2.63$ & \\
\hline \multicolumn{7}{|l|}{ Type of household } \\
\hline Nuclear Family & 480 & 85.7 & 1 & & & \multirow[t]{2}{*}{0.001} \\
\hline Extended Family & 80 & 14.3 & 1.79 & 2.67 & $1.05-3.60$ & \\
\hline \multicolumn{7}{|l|}{ Parent's income } \\
\hline Low & 328 & 58.6 & 1 & & & \multirow{2}{*}{$<0.001$} \\
\hline High & 232 & 41.4 & 4.19 & 1.17 & $3.44-5.90$ & \\
\hline
\end{tabular}




\begin{tabular}{lllllll}
\hline $\begin{array}{l}\text { Cognitive Barriers } \\
\text { No }\end{array}$ & 302 & 54 & 1 & & & 0.000 \\
$\quad$ Yes & 258 & 46 & 2.77 & 3.10 & $5.09-6.98$ & \\
$\begin{array}{l}\text { Psychosocial Barriers } \\
\text { No }\end{array}$ & 288 & 51.4 & 1 & & & $<0.001$ \\
Yes & 272 & 48.6 & 1.83 & 4.21 & $1.11-4.78$ & \\
\hline
\end{tabular}

\subsection{Discussion}

The results of the study indicate that women have barriers to accessing reproductive health information. In this globalization era, information dissemination is quick and easy, especially in information on adolescent reproductive health through print, online, and electronic media [17]. Now, anyone can use the internet and handphone, including parents, adults and even children [18].

Factors related to access to reproductive health information are psychosocial and cognitive barriers [16]. Respondents who experience psychosocial barriers or who are afraid to access reproductive health information are less likely to access reproductive health information [19]. The results of the study show that the factors influencing access to reproductive health information are availability, affordability, acceptance, convenience, and knowledge. Cognitive access barriers indicate ignorance about the availability of health services [20]. Knowledge of the existence of reproductive health information services is related to access to reproductive health information. One of the reasons why adolescents do not visit reproductive health information services is that they do not know the existence of such places. Meanwhile, not all those who know such places visit for consultation [21].

Besides lack of knowledge about the availability of health services, the respondents do not access the health information services because they thought it was unnecessary [22]. A study suggests that students who have risky behavior tend to judge that adolescent reproductive health services are not important as they can access information freely through mass media and the internet [23]. Thus, it becomes one of the barriers to access and information about sexual and reproductive health through health workers [24].

Some intervention options can be used to overcome the cognitive barriers [3]. Based on the findings of a systematic review study, several effective interventions can be used to increase youth access to reproductive health information services. One of them is by connecting the service center with educational institutions in the form of a referral system between health services and educational institutions. Therefore, it can reduce access barriers [15].

Psychosocial barriers indicate obstacles to the acceptance of health services [25]. Culture also makes it difficult for adolescents to openly get knowledge about sex and reproduction [20]. Social stigma in the form of taboos in discussing sexuality and reproductive health limits educational and social space to provide knowledge to adolescents about sexual and reproductive health [26]. Studies show that adolescents do not go to information serviced due to feeling ashamed, not confident, and not trusting health workers to tell stories about their reproductive health problems. Studies on reproductive health information search maps for adolescents confirm that adolescent girls prefer to discuss with their mothers and friends as the first choice to discuss reproductive health problems, then confirm from information media such as the internet [27]. Meanwhile, for boys, the main source is the internet followed by friends and teachers. The internet is used as a reference as they feel freer to access information that is considered taboo or sensitive, such as reproductive health issues [19]. The provision of information services and adolescent-friendly reproductive health services in health facilities is a new intervention, especially in developing countries such as Indonesia. Thus, various studies are needed to determine the effectiveness and challenges in the implementation.

\section{Conclusion}

The respondent in the group that does not experience barriers has a higher tendency to access reproductive health information than those who experience cognitive access barriers. There is a significant relationship between barriers to psychosocial access and gender with access to reproductive health information. There is no relationship between parents' income level and access to reproductive health information. This study can be used as a basis for intervention or improvement of existing reproductive health programs to reduce cognitive and psychosocial barriers experienced by students, especially adolescent boys in an effort to increase access to reproductive health information. Besides, it is necessary to conduct similar studies on access to reproductive health information and examine the obstacles 


\section{Declaration}

Acknowledgments: The authors would like to express the greatest gratitude all respondents who have participated in this research.

Conflicts of Interest: Authors declare there is no conflict of interest in this research

\section{References}

[1] Kemetrian Kesehatan Republik Indonesia, "Basic Health Research 2018," 2018.

[2] D. of R. H. and R. WHO, "WHO recommendations on antenatal care for a positive pregnancy experience WHO Library Cataloguing-in-Publication Data WHO recommendations on antenatal care for a positive pregnancy experience," I.World Heal. Organ. from World Heal. Organ., p. 152, 2016, [Online]. Available: http://apps.who.int/iris/bitstream/10665/250796/1/9789241549912eng.pdf\%0Ahttp://www.who.int.

[3] W. Rahmadhani and A. D. Asti, "Peningkatan Kesehatan Reproduksi Remaja Melalui Pendampingan Kelompok Terapeutik Di Desa Indrosari, Kecamatan Bulus Pesantren, Kebumen," J. EMPATI (Edukasi Masyarakat, Pengabdi. dan Bakti), vol. 1, no. 1, p. 51, 2020, doi: 10.26753/empati.v1i1.425.

[4] Susenas, "Basic Health Research 2018," Riskesda 2016, 2016.

[5] Kemenkes RI, "Situasi Kesehatan Reproduksi Remaja," Situasi Kesehatan Reproduksi Remaja. 2017.

[6] kementerian Kesehatan RI, "Situasi Kesehatan Reproduksi Remaja Dalam Rangka Hari Keluarga Nasional 29 Juni," Pusat Data dan Informasi. 2020.

[7] W. Rahmadhani, J. Suyanto, T. K. Soe, and S. Mutoharoh, "The Relationship Between Husband Support and Behavior of Pregnant Teenagers to Face Pregnancy During the Covid-19 Pandemic in Gombong, Kebumen, Indonesia," Dis. Prev. Public Heal. J., vol. 15, no. 2, 2021, doi: 10.12928/dpphj.v15i2.4413.

[8] W. Rahmadhani, "Pembentukan posyandu remaja di Desa Bejiruyung, Kecamatan Sempor Kabupaten Kebumen," J. Inov. ABDIMAS KEBIDANAN, vol. 1, no. 2, 2021, doi: 10.32536/jiak.v1i2.169.

[9] W. Rahmadhani, "Knowledge Of Postpartum Mothers On Postpartum Care In Healthcare Centers In Kebumen," J. IIm. Kesehat. Keperawatan, vol. 16, no. 1, p. 28, 2020, doi: 10.26753/jikk.v16i1.379.

[10] W. Rahmadhani, "The Affecting Factors of Implementation of Expanding Maternal and Neonatal Survival Program by the Ministry of Health of the Republic of Indonesia in Determining Midwifery in Kebumen, Central Java, Indonesia," 2021, doi: 10.4108/eai.18-11-2020.2311621.

[11] Depkes RI, "Reproduksi Remaja," Situasi Kesehatan Reproduksi Remaja. 2018.

[12] BPS, BKKBN, and Kemenkes RI, "Indonesia Demographic and Health Survey 2017," Kemenkes RI, 2018.

[13] SDKI, "Laporan Pendahuluan Survey Demografi dan Kesehatan Indonesia 2017," in Survey Demografi dan Kesehatan Indonesia 2017, 2017, p. 60.

[14] W. Rahmadhani and W. Laohasiriwong, "Gender of baby and postpartum depression among adolescent mothers in central Java, Indonesia," Int. J. Child Adolesc. Heal., vol. 13, no. 1 PG-43-49, pp. 43-49, 2020, [Online]. Available: https://ezproxy.deakin.edu.au/login?url=http://search.ebscohost.com/login.aspx?dir ect $=$ true\&AuthType $=\mathrm{ip}, \mathrm{sso} \& \mathrm{db}=\mathrm{ccm} \& \mathrm{AN}=145919839 \&$ site $=$ ehost-live\&scope $=$ site NS -.

[15] L. D. Lindberg, D. L. Bell, and L. M. Kantor, " The Sexual and Reproductive Health of Adolescents and Young Adults During the COVID - 19 Pandemic ," Perspect. Sex. Reprod. Health, 2020, doi: 10.1363/psrh.12151.

[16] I. Arifah and M. F. Sharfina, "Hambatan Akses Informasi Kesehatan Reproduksi 
Pada Mahasiswa Kesehatan Universitas Muhammadiyah Surakarta," J. Kesehat., 2019, doi: 10.23917/jk.v11i2.7532.

[17] W. Maryatun, "Metode Clinic-Based Dan Community Empowerment Pada Pemberdayaan Pendidik Dan Konselor Sebaya Dalam Program Kesehatan Reproduksi Remaja Di Kabupaten Sukoharjo," Gaster J. Kesehat., 2011.

[18] F. Violita and E. N. Hadi, "Determinants of adolescent reproductive health service utilization by senior high school students in Makassar, Indonesia," BMC Public Health, 2019, doi: 10.1186/s12889-019-6587-6.

[19] H. Nkata, R. Teixeira, and H. Barros, "A scoping review on sexual and reproductive health behaviors among Tanzanian adolescents," Public Health Reviews. 2019, doi: 10.1186/s40985-019-0114-2.

[20] M. A. Titiloye and A. J. Ajuwon, "Knowledge and quality of adolescents reproductive health communication between parents and their adolescents children in Ibadan, Nigeria," J. Public Health Africa, 2017, doi: 10.4081/jphia.2017.688.

[21] J. M. Kyilleh, P. T. N. Tabong, and B. B. Konlaan, "Adolescents' reproductive health knowledge, choices and factors affecting reproductive health choices: A qualitative study in the West Gonja District in Northern region, Ghana," BMC Int. Health Hum. Rights, 2018, doi: 10.1186/s12914-018-0147-5.

[22] V. Dwi Yani, O. Emilia, and H. Kusnanto, "Persepsi Remaja Terhadap Faktor Penghambat Pemanfaatan Pelayanan Kesehatan Reproduksi Di Puskesmas Gambok Kabupaten Sijunjung," J. Kesehat. Reproduksi, 2014, doi: 10.22146/jkr.4913.

[23] F. Rachmawati, K. Friskarini, L. Nova susanty, H. Edison, R. Prasodjo, and S. Manalu, "Studi Eksplorasi Pendidikan Kesehatan Reproduksi Anak Jalanan Di Rumah Singgah Binaan Pkpr Puskesmas Jakarta Timur," J. Kesehat. Reproduksi, 2020, doi: 10.22435/kespro.v11i1.2819.

[24] W. Rahmadhani, "Pembentukan posyandu remaja di Desa Bejiruyung, Kecamatan Sempor Kabupaten Kebumen," J. Inov. ABDIMAS KEBIDANAN, 2021, doi: 10.32536/jiak.v1i2.169.

[25] C. O. Mbachu et al., "Exploring issues in caregivers and parent communication of sexual and reproductive health matters with adolescents in Ebonyi state, Nigeria," BMC Public Health, 2020, doi: 10.1186/s12889-019-8058-5.

[26] T. Sunarsih, E. P. Astuti, E. F. A. Shanti, and E. R. Ambarwati, "Health promotion model for adolescent reproductive health," Electron. J. Gen. Med., 2020, doi: 10.29333/ejgm/7873.

[27] R. Pourkazemi, M. Janighorban, Z. Boroumandfar, and F. Mostafavi, "A comprehensive reproductive health program for vulnerable adolescent girls," Reprod. Health, 2020, doi: 10.1186/s12978-020-0866-7. 